\section{Early Science at the Royal Society.}

October 4, I667. Mr. Charles Howard suggested, that it might be considered, whether maiz might not yield a kind of sugar, the stalks of it containing a very sweet juice; and he desiring, that he might be furnished with an account of the way of ordering the sugar-canes for the making of sugar, Mr. Oldenburg offered an account relating to Barbadoes.

October 5, I66I. Sir Robert Moray produced unnealed glass hollow balls with a small hole in them; which being held in the hand till they were heated (the hole thereof being stopped with the palm of the hand) would fly to pieces.-Dr. Goddard to try the velocity of sinking bladders in water, and the lord viscount Brouncker in air.-Dr. Ent to give in writing some considerations, why it is hotter in summer than in winter.

October 7, I670. There was read a Latin letter from Signor Montanari, containing some new observations by him of the non-appearance of some stars of the second magnitude in the sky, though formerly observed by Bayer and others; and intimating that he had sent a manuscript, containing various experiments on the breaking of the glass drops, a task imposed on him by the grand duke of Tuscany.

October 8, I662. Mr. Boyle was desired to shew, at the next meeting, the second part of his experiment about coagulation, viz., the reducing the coagulated liquors to their former fluidity.

October 9, I66r. A living chameleon was presented to the society from Mr. Clayton by Dr. Henshaw.Dr. Croune, Dr. Pope and Mr. Rooke were appointed a committee to view the propositions for inquiries in foreign parts.-The lord viscount Brouncker read a letter of Dr. Christopher Wren to Sir Paul Neile, concerning his hypothesis of Saturn.

1673. The president gave the council notice, that there had been lately with him a committee of the professors of Gresham College, and another of the Mercers company, inviting the Royal Society to return to that college, and to keep their assemblies there, as formerly they did before the fire. To whom he had returned his thanks for this kind offer, and for their respect to the Royal Society. The council thought good to have their hearty thanks returned to the said committee for their kindness and respect, yet without saying anything to them of acceptance or not acceptance; only, in case they should give occasion for saying more, that then it might be mentioned, that the business was under consideration. The persons appointed to give these thanks were the lord viscount Stafford, Sir Paul Neile, Sir John Lowther, Mr. Pepys, Mr. Colwall, Dr. Croune and Mr. Oldenburg, or any three of them.-Whilst this was doing, Sir Theodore de Vaux came in, being sent by the earl of Norfolk, earl marshal, to acquaint the council, that his lordship wondered, that they were not met in Arundel-house, as formerly, but yet hoped, that they would hereafter still continue their meetings there, as formerly; and that if they should remove to any other place, he could not but take it very unkindly.-Hereupon the president declared, that for this time he had caused the council to be summoned in this place (his own house?) for his varticular convenience, his present occasions not having permitted him to go far off. And his lordship, at the desire of the council returned their hearty thanks to the earl marshal for his singular affection and respect to the Society.

October II, I669. Ordered that Dr. Merret be desired to send the collection made by Thomas Willisel in his first voyage, to the society at their next meeting at Arundel-house.

\section{Societies and Academies.}

\author{
LONDON.
}

The Institute of Metals (Autumn Meeting), September Io.-D. M. Fairlie and G. B. Brook: The determination of sodium in aluminium.-D. $\mathrm{H}$. Ingall: The relationship between tensile strength, temperature, and cold-work in some pure metals and single solid solutions. The critical inflection temperature is the all-important property of any metal or alloy for high temperature service, as it would appear to be the temperature above which viscous flow may take place and below which there is only stability of the material in the cold-worked state. Other things being equal, the higher the critical inflection temperature, the more suitable is the material. $-\mathrm{H}$. Moore On the effect of progressive cold-rolling on the Brinell hardness of copper. It has been stated that in the cold-rolling of copper, iron, tin and other metals and alloys the Brinell hardness rises rapidly during the initial stages of deformation and then diminishes. Experiments carried out at the Research Department, Woolwich, give no support to the suggestion that severe cold-rolling of copper beyond a certain stage induces softening.-F. W. Rowe: (I) Some experiments on the effect of casting temperature and heattreatment on the physical properties of a high-tin bronze. The bronze of the highest tin content (copper, $86 \cdot 0$ : tin, I $5 \cdot 95:$ phosphorus, $0 \cdot 05$ ) used in engineering practice is employed for special bearings where low tin phosphor bronzes and leaded phosphor bronzes have been found unsatisfactory. This alloy attains its greatest hardness (and probably best wearing properties) with the lowest casting temperature; this is, however, very often not practicable on account of the danger of "draws" in uneven sectioned castings. - (2) Some experiments on the influence of casting temperature and mass on the physical properties of Admiralty gun-metal. Admiralty gun-metal (copper, $88:$ tin, Io: zinc, 2 ) gives the best results in all sizes of bars with the lowest casting temperature, i.e. II $100^{\circ} \mathrm{C}$., and the best tests of all with the $\frac{1}{2}$ in. square bar cast at that temperature.Tomojiro Tanabe: Studies in the aluminium-zinc system.-T. H. Turner and W. E. Ballard: Metal spraying and sprayed metal. The process of metallisation invented shortly before the War and known generally as Schoop's metal spray process was held back in its development by the unsettled condition of industry, but is now being operated commercially. The gas-operated metal spraying pistol now used in Great Britain and a rumbling barrel type of metallising apparatus which is used for repetition work on small articles were illustrated. All articles to be sprayed are sandblasted and, in certain cases, preheating of the article to be coated is recommended, as this also tends to improve the adhesion. By spraying lightly on to glass slips it has been possible to examine the individual particles of the sprayed metals. Photomicrographs of these show that the metal must be molten at the instant it strikes the surface to be coated. Solid articles have been built up by spraying and proved machineable and resonant. Practically any metal available in wire form and fusible in the oxy-hydrogen flame may be sprayed on to practically any surface, e.g. on to paper, fabric, wood, or metal. The surface produced is always matte, but may be polished if desired. The matte surface is an ideal foundation for paints. Completed structures can be coated uniformly with any desired metal for protection against atmospheric corrosion, chemical attack, or furnace conditions. The process has found a particular field in ship work, and is recommended for the zincing of rail ends and fishplates for connecting purposes on electric railways. 